\section{REFERENCES}

Adélaïde J, Penault-Llorca F, Dib A, Yarden Y, Jacquemier J, Birnbaum D (1994) The Heregulin gene can be included in the 8p12 amplification unit in breast cancer. Genes Chromosomes Cancer 11: 66-69

Adélaïde J, Chaffanet M, Imbert A, Allione F, Geneix J, Popovici C, van Alewijk D, Trapman R, Zeillinger R, Borresen-Dale AL, Liderau R, Birnbaum D, Pébusque M-J (1998) Chromosome 8p11-p12 region: refined mapping and molecular alterations in breast cancer. Genes Chromosomes Cancer 22: $186-199$

Adélaïde J, Chaffanet M, Mozziconacci M-J, Popovici C, Conte N, Fernández F, Sobol H, Jacquemier J, Pébusque M-J, Ron D, Lafage-Pochitaloff M, Birnbaum D (2000) Translocation and coamplification of loci from chromosome arms $8 \mathrm{p}$ and $11 \mathrm{q}$ in the MDA-MB-175 mammary carcinoma cell line. Int J Oncol 16: 683-688

Burden S, Yarden Y (1997) Neuregulins and their receptors: a versatile signalling module in organogenesis and oncogenesis. Neuron 18: 847-855

Carraway KL, Carraway CA, Carraway KL (1997) Roles of ErbB3 and ErbB4 in the physiology and pathology of the mammary gland. J Mammary Gland Biol Neoplasia 2: $187-198$

Courtay-Cahen C, Morris JS, Edwards PAW (2000) Chromosome translocations in breast cancer with breakpoints at 8p12. Genomics 66: 15-25

Holmes WE, Sliwkowski MX, Akita RW, Henzel WJ, Lee J, Park JW, Yansura D, Abadi N, Raab H, Lewis GD, Shepard HM, Kuang W-J, Wood WI, Goeddel DV, Vandlen RL (1992) Identification of Heregulin, a specific activator of $\mathrm{p} 185^{\mathrm{erbB} 2}$. Science 256: $1205-1210$

Le X-F, McWatters A, Wiener J, Wu J-Y, Mills GB, Bast Jr RC (2000) AntiHER2 antibody and heregulin suppress growth of HER2-overexpressing human breast cancer cells through different mechanisms. Clin Cancer Res 6: $260-270$

Lee J, Wood WI (1993) Assignment of heregulin (HGL) to human chromosome 8 p22-p11 by PCR analysis of somatic cell hybrid DNA. Genomics 16: $790-791$

Lewis GD, Figari I, Fendly B, Wong WL, Carter P, Gorman C, Shepard HM (1993) Differential responses of human tumor cell lines to anti-p185HER2 monoclonal antibodies. Cancer Immunol Immunother 37: 255-263

Liu X, Baker E, Eyre HJ, Sutherland GR, Zhou M (1999) $\gamma$-Heregulin: a fusion gene of DOC-4 and neuregulin-1 derived from a chromosome translocation. Oncogene 18: $7110-7114$
Lupu R, Cardillo M, Cho C, Harris L, Hijazi M, Perez C, Resenberg K, Yang D, Tang C (1996) The significance of heregulin in breast cancer tumor progression and drug resistance. Breast Cancer Res Treat 38: 57-66

Morris J, Carter N, Ferguson-Smith M, Edwards P (1997) Cytogenetic analysis of three breast carcinoma cell lines using reverse chromosome painting. Genes Chromosomes Cancer 20: 120 - 139

Peles E, Yarden Y (1993) Neu and its ligands: from an oncogene to neural factors. Bioessays 15: 815-824

Ram TG, Kokeny KE, Dilts CA, Ethier SP (1995) Mitogenic activity of neu differentiation factor/heregulin mimics that of epidermal growth factor and insulin-like growth factor-I in human mammary epithelial cells. J Cell Physiol 163: 589-596

Schaefer G, Fitzpatrick VD, Sliwkowski MX (1997) $\gamma$-Heregulin: a novel heregulin isoform that is an autocrine growth factor for the human breast cancer cell line, MDA-MB-175. Oncogene 15: 1385-1394

Sánchez I, San Miguel JF, Corral J, Martín C, Pérez R, González M, Cañizo MC, Orfao A, González-Sarmiento R (1995) Gene rearrangement in Acute non-lymphoblastic leukemia. Correlation with morphological and immunophenotypic characteristics of blast cells. Br J Haematol 89: 104-109

Utada Y, Haga S, Kajiwara T, Kasumi F, Sakamoto G, Nakamura Y, Emi M (2000) Allelic loss at the $8 \mathrm{p} 22$ region as a prognostic factor in large and estrogen receptor negative breast carcinoma. Cancer 88: 1410-1416

Wang X-Z, Jolicoeur EM, Conte N, Chaffanet M, Zhang Y, Mozziconacci M-J, Feiner H, Birnbaum D, Pébusque M-J, Ron D (1999) $\gamma$-heregulin is the product of a chromosomal translocation fusing the DOC4 and HGL/ NRG1 genes in the MDA-MB-175 breast cancer cell line. Oncogene 18: $5718-5721$

Weinstein EJ, Grimm S, Leder P (1998) The oncogene heregulin induces apoptosis in breast epithelial cells and tumors. Oncogene 17: 2107-2113

Yokota T, Yoshimoto M, Kasumi F, Sakamoto G, Nakamura Y, Emi M (1999) Localization of a tumor suppressor gene associated with the progression of human breast carcinoma within a 1-cM interval of 8p22-p23.1. Cancer 85: $447-452$

\title{
Early life exposure to oestrogen and testicular cancer risk: evidence against an aetiological hypothesis
}

\section{Hsieh*,', M Lambe', D Trichopoulos ${ }^{3}$, A Ekbom², O Akre², H-O Adami ${ }^{2}$}

'University of Massachusetts Cancer Center, 373 Plantation Street, Suite 202, Worcester, Massachusetts, MA 01605, USA; ${ }^{2}$ Department of Medical Epidemiology, Karolinska Institute, Stockholm, Sweden; ${ }^{3}$ Department of Epidemiology and Center for Cancer Prevention, Harvard School of Public Health, Boston, Massachusetts, MA 02115, USA

\section{DOI: 10.1038/sj/bjc/6600246 www.bjcancer.com}

(c) 2002 Cancer Research UK

Sir

Testicular cancer has a peak incidence among men aged 25 to 34 years, suggesting early life influences (Akre et al, 1996). The hypothesis that exposure to endogenous or environmental oestrogenic compounds affects embryonic testis and increases the risk of testicular cancer has been put forth (Sharpe and Skakkeback, 1993). This intriguing hypothesis has acquired momentum and,

\footnotetext{
*Correspondence: CC Hsieh; E-mail: chung.hsieh@umassmed.edu
}

in fact, was invoked as the main aetiologic mechanism in a recent major review (Dearnaley et al, 2001). If prenatal exposure to oestrogens were indeed important, one would expect that populations with higher levels of pregnancy oestrogens would experience a higher rate of testicular cancer. We have studied pregnancy hormone levels, including oestrogen levels, in two populations with very different rates of testicular cancer (Lipworth et al, 1999).

Adult pregnant women were recruited from maternity clinics of Beth Israel Hospital in Boston, MA, USA, and from hospitals 
affiliated with the Shanghai Medical University in Shanghai, China. Pregnant women were enrolled during their first prenatal visit to the collaborating maternity clinic. Eligibility requirements included that the pregnant women had to be less than 40 years old, had no more than one previous stillborn or liveborn child, took no hormonal medication during the index pregnancy and had no prior diagnosis of diabetes mellitus or thyroid disease. Three hundred and four Caucasian women in Boston and 335 Chinese women in Shanghai were studied. Pregnancy serum concentrations of oestradiol-17 $\beta$ (E2) and unconjugated oestriol (E3) were measured in maternal blood at weeks 16 and 27 of gestation. Details of the study have been published in this journal (Lipworth et al, 1999). Levels of E2 and E3 were consistently and significantly higher among Chinese women at both sample 1 and sample 2 (Table 1). The age-standardised rate as well as age-specific incidence rates of testicular cancer during the period of 1988-1992 for white and Chinese males (aged 15-49) were obtained from the Connecticut and the Shanghai Cancer Registries, respectively
(Parkin et al, 1997). The rates for Chinese males in Shanghai at all ages were much lower than those for white males in Connecticut, despite evidence of exposure to higher levels of oestrogens in utero.

While the hypothesis linking high oestrogen exposure with testicular cancer and other disorders of the male reproductive system is ingenious, empirical support so far has been limited. Our data are incompatible with this hypothesis and, although they do not conclusively refute it, tend to reduce its plausibility.

\section{ACKNOWLEDGEMENTS}

This study was supported in part by a grant from the US National Institutes of Health, National Cancer Institute (R01 CA54220).

Table I Pregnancy serum concentrations of oestradiol (E2), and oestriol (E3) in Chinese women (Shanghai, China) and Caucasian women (Boston, USA) (upper panel); age standardised and age-specific rates of testicular cancer for Chinese and US males during 1988- 1992 (lower panel)

\begin{tabular}{|c|c|c|c|c|}
\hline & \multicolumn{4}{|c|}{$\begin{array}{l}\text { Pregnancy oestrogen concentrations (nmol I }{ }^{-1} \text {, mean } \pm \text { s.d.), } 1994-1995 \\
\text { (Lipworth et al, 1999) }\end{array}$} \\
\hline & \multicolumn{2}{|c|}{$\begin{array}{l}\text { Samples at } 16 \text { th weeks of } \\
\text { gestation }\end{array}$} & \multicolumn{2}{|c|}{$\begin{array}{c}\text { Samples at } 27 \text { th weeks of } \\
\text { gestation }\end{array}$} \\
\hline & E2 & E3 & E2 & E3 \\
\hline $\begin{array}{l}\text { Shanghai, China } \\
\text { Boston, US }\end{array}$ & $\begin{array}{l}20.7 \pm 9.7 \\
14.0 \pm 6.4\end{array}$ & $\begin{array}{l}6.3 \pm 3.9 \\
3.9 \pm 1.7\end{array}$ & $\begin{array}{l}48.2 \pm 18.3 \\
39.1 \pm 16.6\end{array}$ & $\begin{array}{l}21.9 \pm 9 \\
14.0 \pm 4\end{array}$ \\
\hline
\end{tabular}

\begin{tabular}{lccccccccc} 
& \multicolumn{7}{c}{ Age-specific incidence rate of testicular cancer (per 100 000), 1988- 1992} \\
& ASR & $\mathbf{1 5 - 1 9}$ & $\mathbf{2 0 - 2 4}$ & $\mathbf{2 5 - 2 9}$ & $\mathbf{3 0 - 3 4}$ & $\mathbf{3 5 - 3 9}$ & $\mathbf{4 0 - 4 4}$ & $\mathbf{4 5 - 4 9}$ \\
\cline { 2 - 9 } & 0.74 & 0.24 & 0.63 & 0.39 & 1.71 & 1.53 & 1.44 & 0.56 \\
\hline Shanghai, China & 5.29 & 3.60 & 9.68 & 14.36 & 14.87 & 12.28 & 9.14 & 5.81 \\
Connecticut, US, Whites
\end{tabular}

ASR: age standardised rate, adjusting all the age-specific rates in 5 year category $(0-4,5-9, \ldots, 80-84,85+)$ to standard world population (Parkin et al, 1997)

\section{REFERENCES}

Akre O, Ekbom A, Hsieh CC, Trichopoulos D, Adami H-O (1996) Testicular nonseminoma and seminoma in relation to perinatal characteristics. J Natl Cancer Inst 88: 883-889

Dearnaley DP, Huddart RA, Horwich A (2001) Managing testicular cancer. BMJ 322: $1583-1588$

Lipworth L, Hsieh CC, Wide L, Ekbom A, Yu SZ, Yu GP, Xu B, Hellerstein S, Carlstrom K, Trichopoulos D, Adami H-O (1999) Maternal pregnancy hormone levels in an area with a high incidence (Boston, USA) and in an area with a low incidence (Shanghai, China) of breast cancer. $\mathrm{Br} J$ Cancer 79: 7-12
Parkin DK, Whelan SL, Ferlay J, Raymond L, Young J (1997) Cancer incidence in five continents. Volume VII, IARC Scientific Publications No. 143, Lyon: IARC

Sharpe RM, Skakkeback NE (1993) Are oestrogens involved in falling sperm counts and disorders of the male reproductive tract?. Lancet 341: 1392 1395 